\title{
ASSESSMENT AND ANALYSIS OF HEAT PROVISION VULNERABILITY IN THE MAIN WINE-PRODUCING REGION OF ARMENIA (ARARAT VALLEY AND FOOT- HILL AREA) WITHIN THE CONTEXT OF EXPECTED CLIMATE CHANGE
}

\author{
V. G. Margaryan ${ }^{1}$, Cand. Sci. (Geogr.) \\ M. S. Mkhitaryan ${ }^{2}$ \\ ${ }^{1}$ Yerevan State University, Alek Manoukian Street 1, 0025 Yerevan, \\ Republic of Armenia, vmargaryan@ysu.am \\ ${ }^{2}$ Ministry of Emergency Situations of the Republic of Armenia, \\ Service for Hydrometeorology and Active Impact on Atmospheric Phenomena, \\ 109/8 A. Mikoyan Str. 4th Block of Davitashen, 0054 Yerevan, Republic of Armenia
}

\begin{abstract}
The paper reviews and assesses heat provision conditions of Armenia's main wine-producing region (Ararat Valley and foothill area), analyzes the patterns of temporal distribution of heat provision and determines how they are affected by the global climate change.

It demonstrates increase of active temperatures observed in the main wine-producing region.

Keywords: grape, heat provision, vulnerability, climate change, main wine-producing region, Ararat Valley and foothill area.
\end{abstract}

\section{INTRODUCTION}

One of the important factors of grape vine vitality is the heat, which characterizes the possibility of grape cultivation under the conditions. If heat conditions are good during the vegetation, the process of growth and development of all organs of vine will be better, high and quality yield from planting stock will be obtained. The problem is even more important, especially under the climate change, as in the territory of the country, an increase in climate aridity and decrease of rainfall are predicted.

Given the above, we intend:

- to examine and evaluate the heat provision conditions of the country's main industrial region of viticulture (the Ararat Valley and the foothill zone) in the paper,

- analyze and find out the patterns of temporal distribution of heat providing, in the context of global climate change.

\section{THE STUDY AREA}

The Ararat Valley is one of the subregions of the physical-geographical area of Ararat. It has $100 \mathrm{~km}$ length within the Republic, the width in the northwestern part reaches reaches $15-17 \mathrm{~km}$, in the southeastern part $-4-5 \mathrm{~km}$. The surface is generally flat. The height of the area is $800-1000 \mathrm{~m}$ above a sea level. The foothill zone includes southern slopes of Aragats mass, up to 1600 meters, highlands of Yeghvard and Kanaker, western slopes of the Arpa River basin and the foothills part, up to $1600 \mathrm{~m}$ height. The landscape of the Ararat Valley is a de- sert - a semidesert, characterised by sierozem. At some locations sandy hills, alkaline soil and salt marshes are met. Most of the plain is cultivated and covered with cultural-irrigated lands. The virgin part of the area is covered with halophyte and xerophilous vegetation and wormwood, and the culturalirrigated areas are covered with gardens of fruittrees and vineyards, cotton plantations and other agricultural crops. In foothill zones chestnut soils dominate and pass to chernozem in the upper limit. It is typical for various grass steppe vegetations. In a relatively low part of the area podzolic and brown soils appear which are sometimes intermitted by alkaline soil and salt marsh [1].

The feature of climate characteristic of study area is a sharp continentality (that is, area has sharp continental climate) with great fluctuations of annual and daily temperature and air humidity. The annual temperature amplitude is over than $63,0 \ldots 75,0^{\circ} \mathrm{C}$ (in winter $-26,1 \ldots-32,6^{\circ} \mathrm{C}$, in summer $-37,5 \ldots 42,6^{\circ} \mathrm{C}$ ), while annual rainfall is 200 $300-400-450 \mathrm{~mm}$. The Ararat Valley and the foothill areas are considered one of the driest areas in the Transcaucasia, especially in the lower part.

The region's climatic conditions are favorable for cultivation of various crops, subtropical fruits (pomegranate, fig, olive, almond), fruits orchards (peaches, apricots, apples, pears), technical (cotton, etc.), cereal, tuber and other crops. The Ararat Valley and the foothill areas are the main agricultural production areas. Here agriculture develops due to irrigation. 


\section{THE MATERIAL AND METHOD}

In order to solve the problems, relevant studies, published works, reports, development programs, projects have served as a theoretical and informational basis [1-10]. As a source material, daily data from actual observations at meteorological stations in the study area of the Ministry of Emergency Situations of the Republic of Armenia "Service for Hydrometeorology and Active Impact on Atmospheric Phenomena", as well as agroclimatic reference-books are used.

Grape is a crop of temperate warm zone, which has the best conditions for cultivation: between 35 $45^{\circ}$ north latitude and the industrial cultivation is possible between $20^{\circ}$ and $47-54^{\circ}$ north latitude. In subtropical conditions the vine is an evergreen plant and gives a low yield with bad quality. The grapes are cultivated under different soil-climatic conditions in Armenia. Moreover, more than $83 \%$ of vineyards are in the closed vineyard areas. The grape is used in a fresh state and for the predominant national traditional wine and brandy-exclusive production material as well. Viticulture is the most profitable branch of agriculture in Armenia. Here the grape plantation area was 13,1 thousand ha in 2005 , the yield was $71.4 \mathrm{c} / \mathrm{ha}$, the harvest 81,6 thousand.

Among the five viticultural areas of the Republic, the first one is the Ararat plain, which had $66 \%$ of a total area of vineyard before the Soviet Union's collapse and up to $81 \%$ of gross output of grape and by average data for $2010-71,2$ and $85,6 \%$ accordingly [2].

In the Ararat Valley and the foothills white Sateni, pink Kishmish, Nazeli, Ararat, Mskhali, Itsaptuk, White Muscat grape varieties are cultivated, which require different amounts of heat for their cultivation. Thus different varieties of vine, beginning from the breaking of buds to full ripeness, take about 109 to 169 days, and require the total temperature above $10.0^{\circ} \mathrm{C}$ of about 2200 to 3000 $3600{ }^{\circ} \mathrm{C}$ [2]. Even the same grape variety, depending on the area's height above sea level, the relief, the slope exposure, and consequentially, the amount of active temperatures accumulates different amounts of sugar and acids in fruits, which directly effects the chemical indicators and the quality of wine. As a methodological basis for the work a mathematics-statistics and an extrapolation analyses as well as the correlation methods are applied in the work in question.

\section{RESULTS AND DISCUSSION}

The climate has a direct impact on a vine growth and yield. Among with the climatic conditions the heat is particularly important for the vitality of vine that characterizes the probability for cultivation of vine, the average period and duration of vine phases during the vegetation period, the total amount of active temperatures in this period. Grape's vegetation starts in spring with crying [2,3], when an average daily air temperature is above 8.0 to $10.0^{\circ} \mathrm{C}$ and ends in autumn, when an average daily temperature decreases to $8,0 \ldots 10,0^{\circ} \mathrm{C}$ and lower. In $15-25$ days upon crying, when an average daily temperature exceeds $11,0 \ldots 12,0^{\circ} \mathrm{C}$, the buds open; blooming is observed 35-57 days after opening of the buds, when the average daily air temperature is $18,0 \ldots 21,0^{\circ} \mathrm{C}$ :

Heat provision is the amount of heat required for finishing an annual cycle of a crop development. It is expressed with the sum of average daily temperatures (the amount of biological temperatures), which accumulate from the beginning of vegetation to a crop maturity. Heat provision of agricultural crops is characterized by the amount of temperatures above $5,0^{\circ} \mathrm{C}$ and $10,0^{\circ} \mathrm{C}$. Heat provision and duration of a vegetation period depend on the sum of temperatures above 10 degrees (active temperatures), it has some effect on the variety choice, a sugar accumulation in fruit and specialization in viticulture. According to the actual observations in the study area, the annual amount of temperatures above $10,0{ }^{\circ} \mathrm{C}$ is $3176^{\circ} \mathrm{C}$ (Garni) to $4220^{\circ} \mathrm{C}$ (Ararat) on average. As a result, the thermal conditions of the region are favorable for the accumulation of large amounts of sugar in the grape fruit.

In table 1 the long-term average periods of a grape growth and the sum of temperatures above $10,0^{\circ} \mathrm{C}$ in the Ararat Valley and the foothills are summarized.

It should be noted that the studies show [4], that on the southern slopes of $500-2000 \mathrm{~m}$ in the dry regions of the Republic a sum of temperatures of above $10,0{ }^{\circ} \mathrm{C}$, accumulate $400-600{ }^{\circ} \mathrm{C}$ more than on the northern slopes. Therefore, the same crop can be developed on the southern slopes in about 250$350 \mathrm{~m}$ higher elevations than on the northern slopes. 
Table 1 - The average periods of grape development phases and the sum of necessary temperatures $\left(\Sigma>10,0^{\circ} \mathrm{C}\right)$

\begin{tabular}{|l|c|c|c|c|c|c|c|}
\hline \multirow{2}{*}{ Charactericstics } & \multicolumn{7}{|c|}{ Phases of Growth } \\
\cline { 2 - 7 } & crying & $\begin{array}{c}\text { swelling of } \\
\text { buds }\end{array}$ & $\begin{array}{c}\text { opening of } \\
\text { buds }\end{array}$ & $\begin{array}{c}\text { opening } \\
\text { of III leaf }\end{array}$ & $\begin{array}{c}\text { bloomin } \\
\mathrm{g}\end{array}$ & $\begin{array}{c}\text { full } \\
\text { ripeness }\end{array}$ & harvest \\
\hline \multicolumn{7}{|c|}{ The Ararat valley } \\
\hline date & $03 / 04$ & $14 / 04$ & $20 / 04$ & $30 / 04$ & $05 / 06$ & $01 / 09$ & $29 / 09$ \\
\hline $\boldsymbol{\Sigma}>\mathbf{1 0}^{\circ} \mathbf{C}$ & 52 & 177 & 182 & 332 & 1057 & 3173 & 3748 \\
\hline \multicolumn{7}{|c|}{ Foothill zone } \\
\hline date & $08 / 04$ & $22 / 04$ & $30 / 04$ & $12 / 05$ & $16 / 06$ & $18 / 09$ & $12 / 10$ \\
\hline $\boldsymbol{\Sigma}>\mathbf{1 0}^{\circ} \mathbf{C}$ & 4 & 100 & 130 & 440 & 950 & 2840 & 3180 \\
\hline
\end{tabular}

Table 2 - The heat requirements (a sum of temperatures above 10 degrees) for cultivation of early-ripe and late-ripe varieties of grape in the Ararat valley and the upper climatic zone of their spread [4]

\begin{tabular}{|c|c|c|}
\hline $\begin{array}{c}\text { Minimum biological tempera- } \\
\text { tures of growth in air }\end{array}$ & $\begin{array}{c}\text { Amount of requirement of bio- } \\
\text { logical temperatures }\end{array}$ & $\begin{array}{c}\text { A sea level (m), where biological tem- } \\
\text { peratures provide the yield ripeness }\end{array}$ \\
\hline $8-9$ & $2100-3700$ & $1500-1800$ \\
\hline
\end{tabular}

Comparing the demand of crops to the sum of temperatures of above 5,0 and $10,0{ }^{\circ} \mathrm{C}$ to the respective average values typical of this area (table 2 ) it is possible to find out what kind of crop is expedient to use there.

The studies show that in the region the amount of temperatures above 5,0 and $10,0^{\circ} \mathrm{C}$ are more than the sum of the temperatures necessary for a crop cultivation. It means that in the region thermal conditions are favorable for grape cultivation, as well as for different crops (subtropical, technical, fruits, cereal, vegetable and melon crops and other). However, the risk of late spring and early autumn frosts should also be considered.

We have graphically presented the average terms of the development of grape in the Ararat valley and the foothills zone, where the necessary sum of temperatures above $10,0^{\circ} \mathrm{C}$ is also taken into account (fig. 1). In this graph we can determine how much cumulative temperature is needed for the development of this phase.

The studies have shown that in the main industrial viticulture region of the republic a tendency of increase in the sum of temperatures of above $10,0{ }^{\circ} \mathrm{C}$ is observed (fig. 2). Its persistence will bring a change to the grape's quality, the shape, the taste, the spread of diseases and their geographic expansion.

It is expected that up to 2100 the impact of the climate change will move the cultivation zone for each crop, including the grape, $100-200 \mathrm{~m}$ to $400 \mathrm{~m}$ up. On the other hand, the combination of an increase in the temperature and evaporation and a decrease in precipitation will bring a reduction to grape productivity, an additional demand of irrigation water, a secondary salinization of the soil, thus, a cost increase. It is naturally enough to make serious scientific researches, work out a new strategy, find out new zones for vineyard and develop new varieties to meet the aforesaid conditions.

The climate change will also have a significant effect on the agricultural crop yield So in the third national message on the climate change, the effect of the climate change on the main agricultural crops was assessed. A decrease in the harvest for grape has been predicted both for the irrigated and the non-irrigated conditions.

Table 3 shows the average values for a sum of temperature of above 10 degrees and the predicted changes (\%) by the average for 1966-2015 for the years of 2030, 2050, 2070 and 2100. According to the table 3 , an increase of necessary temperatures for grape cultivation is observed in the study area.

Thus, under the impact of the climate change, a tendency towards an increase in both the average annual air temperature $[5-6,8]$ and the amount of active temperatures [9-10] is observed in the study area. It turns out that in the study area, under the conditions of an expected increase in the temperature, the vegetative period duration also increases. 


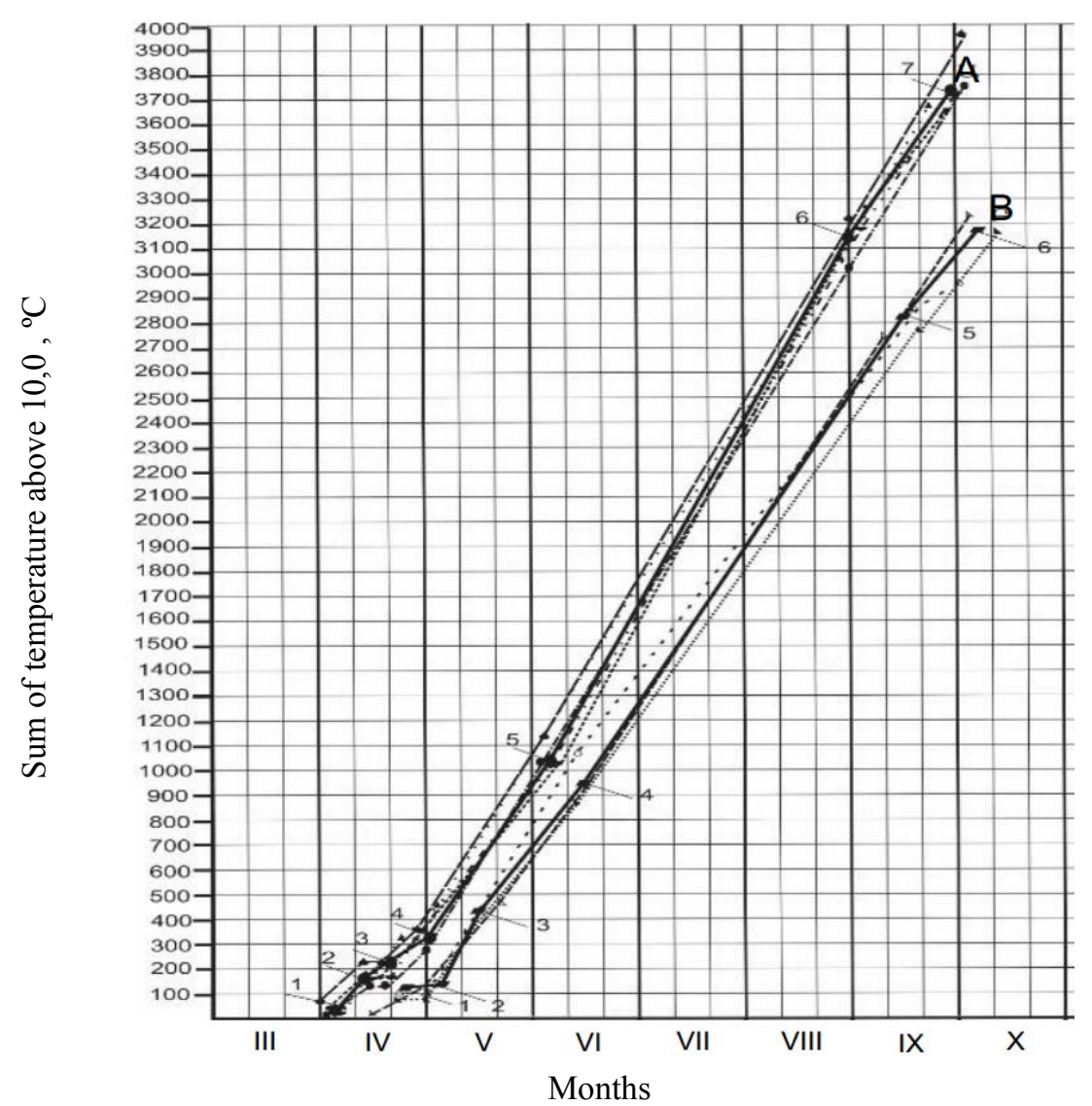

Fig. 1 - The long-term average period of a grape growth and a necessary sum of temperatures Above $10,0{ }^{\circ} \mathrm{C}$ in the Ararat valley (A) and the foothills zone (B):1-crying, 2-swelling of buds, 3-opening of buds, 4-opening of III leaf, 5-blooming, 6-full ripeness, 7-harvest.

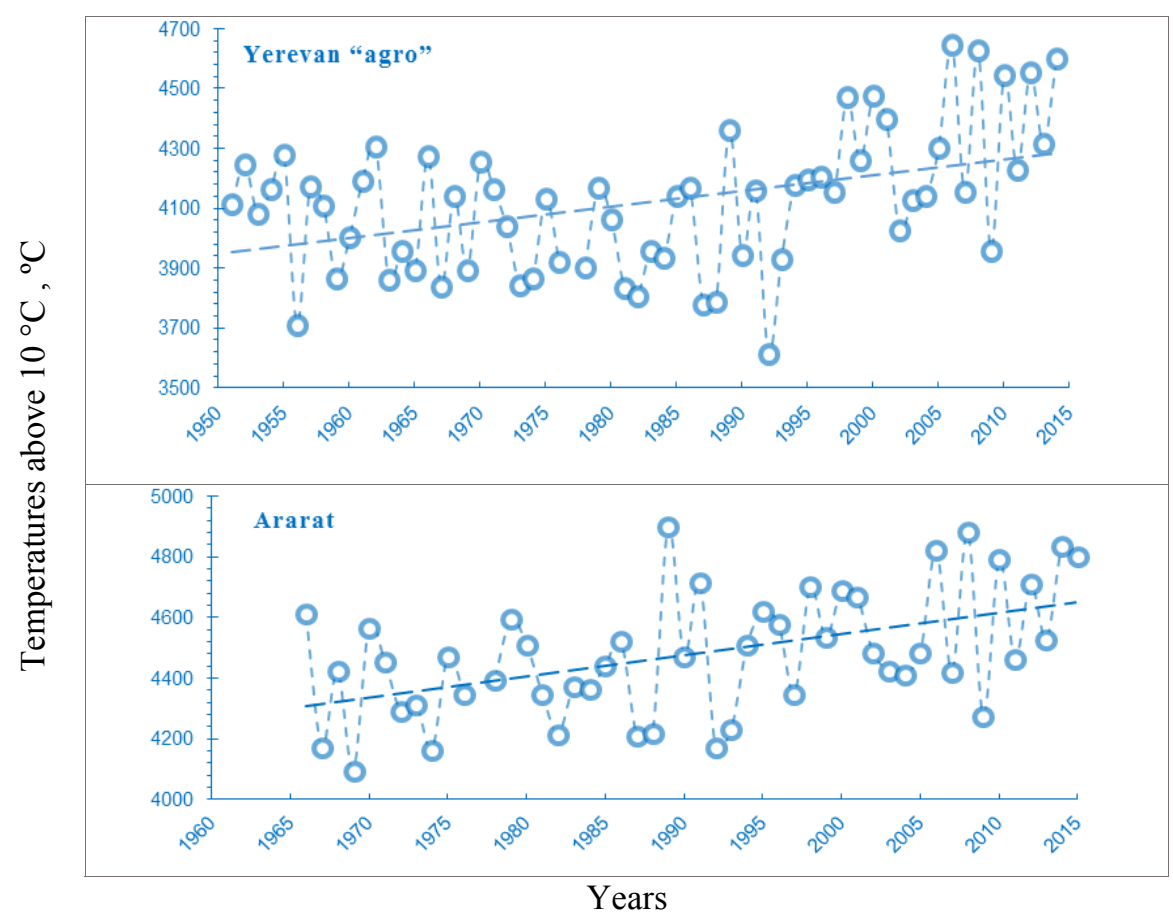

Fig. 2 - Dynamics change of the sum of temperatures above $10^{\circ} \mathrm{C}$ in a vegetation period (March-October) at Yerevan agro and Ararat meteorological stations 
Table 3 - The average values and predicted changes of the sum of active temperatures by the average of 1966-2015 period (\%)

\begin{tabular}{|c|c|c|c|l|l|l|}
\hline \multirow{2}{*}{ Meteor. Stations } & \multicolumn{2}{|c|}{ Middle period } & \multicolumn{4}{c|}{ Change by trend (\%) } \\
\cline { 2 - 7 } & $1961-1990$ & $1966-2015$ & 2030 & 2050 & 2070 & 2100 \\
\hline Yerevan "Agro" & 4015 & 4145 & +5 & +8 & +10 & +14 \\
\hline Ararat & - & 4480 & +6 & +9 & +12 & +17 \\
\hline
\end{tabular}

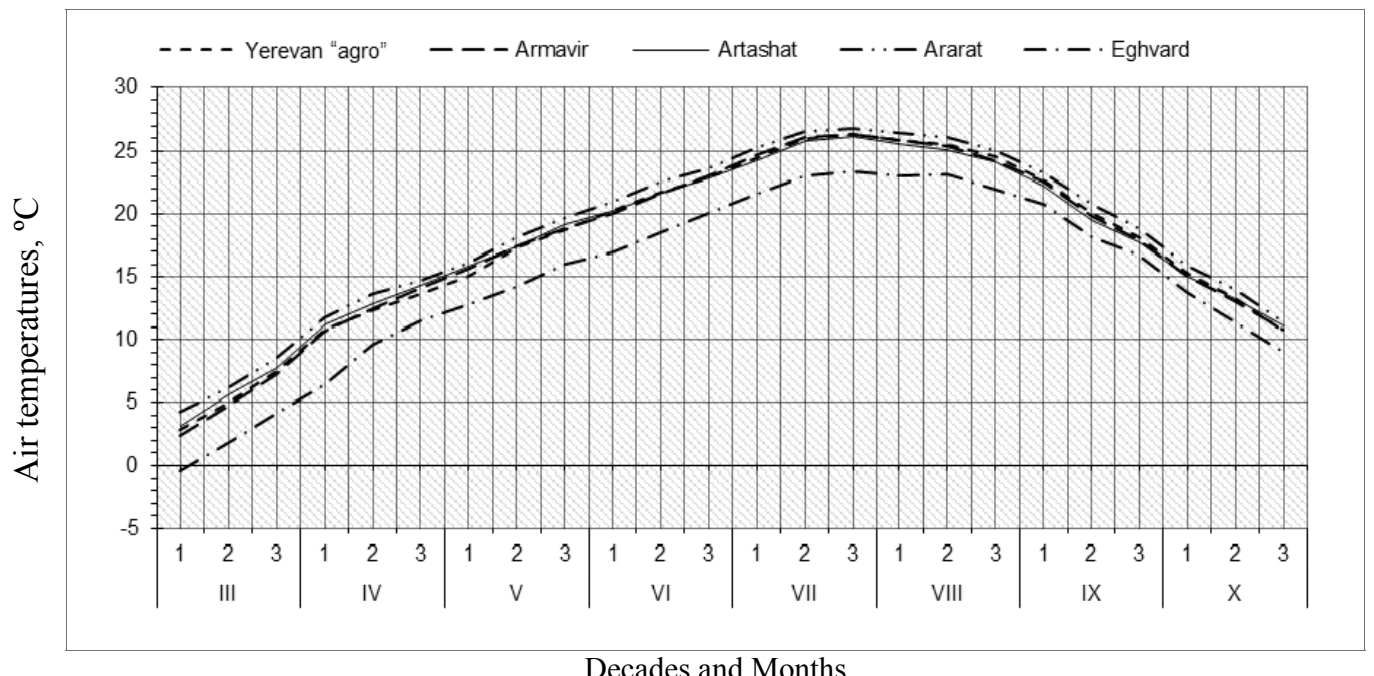

Fig. 3 - The process of average ten-day air temperatures in a vegetation period in the Ararat valley and the foothill zone

That is, in the issue, the vegetation begins earlier, which on the one hand creates favorable thermal conditions for grape cultivation and, on the other hand, increases the degree of vulnerability of grape to unfavorable and dangerous meteorological phenomena.

As brandy wine materials, fortified sweet, dessert, table wine and grape juice production are specialized in the Ararat valley, the production of table dry wines will become difficult and impossible to implement in view of the climate change. The reason is that the grape sugariness will increase sharply and will not correspond to standard conditions. The cultivation of these varieties should be moved to a foothill zone. The viticulture of the Ararat Valley will be exclusively specialized on a brandy wine material, fortified sweet and dessert wines as well as grape juice production. On the other hand, during the latest 2-3 decades the grape areas are sharply separated, the handwork has become dominant, in the most cases vineyards are not closed, vines freeze, the crop yield reduced, diseases and pests become widespread. The latter is one of the priority issues in the sector, which has not been provided a solution for and requires lots of efforts and substantial financial investment.

For the grape cultivation, it is also important to know the average ten-day air temperatures in a vegetation period by months. Based on the actual values of the average ten-day air temperatures, their distribution in a vegetation period has been made (fig. 3). It allows to ascertain the average terms for a grape growth in the study area and to regulate and plan the field works by taking the weather conditions of a particular year into account.

So, it is necessary to make a serious scientific researches, to work out new strategies, to find new areas for vineyards and to work out more productive new kinds for these conditions.

\section{CONCLUSIONS AND RECOMMENDATIONS}

In the result of the studies we came to the following conclusions and recommendations:

- The region is known for its great potential of thermal resources;

- In the latest $70-80$ years, a stable change of climatic elements with the temperature increase is observed;

- It is supposed that in 2100 in a vegetation period (March-October) there will be observed an increase of an active temperatures sum from 600700 to $1000{ }^{\circ} \mathrm{C}$ as compared to the present average, an increase of grape sugariness, lift of the upper limit of cultivation of up to 1600-1800 m, an expansion of the vineyard areas, an increase of the production of the exported red wines;

- Climate change will have its impact on a 
grape harvest which will lead to some downfall;

- In view of the climate change, a shift in phenological phases of the crops and cultivation borders is expected. It is possible that the vegetation of the crop will begin earlier and end later, the upper limit borders of crops may move up to $100-200 \mathrm{~m}$ higher figures.

It is necessary to :

- provide and implement comprehensive, systemized and uninterrupted views;

- expand the irrigated area;

- invest in a new and drought-resistant highyielding varieties

- invest in and apply new and integrated technologies of grape cultivation, which will somewhat mitigate the adverse effects of the climate change;

- work out definite mechanisms aimed at combatting hazardous hydrometeorological phenomena, causing a damage to viticulture, combined with prevention of social detriment and economic loss.

\section{REFERENCES}

1. Baghdasaryan, A.B. (1958). The climate of Armenian SSR. Yrevan : Publ. House of the Armenian SSR Academy of Sciences.

2. Ayvazyan, P.K., Ayvazian, G., Barseghyan, Mr. (2015). The main grape varieties spreaded in Armenia. Viticulture and wine production specialization and distribution of varieties. Manual. Yerevan : ALIS.

Fulga, I.G. (1989). Fundamentals of viticulture and fruit growing. 2nd ed., revised and completed. Moscow: Agropromizdat.
3. Mkrtchyan, R.S., Melkonian, D.H., Badalyan, V.H. (2011). Agroclimatic resources of Armenia. MES of Armenia \& Hydrometeorological and Monitoring Service of Armenia "Armstatehydromet". Yerevan: Lusabats.

4. Margaryan, V.G. (2016). The dynamics change of average annual values of air temperature in instrumental period (on the pattern of mountainous territory of the Republic of Armenia). The Conference Global Climate Observation: the Road to the Future, 2-4 March, Amsterdam, pp. 37-38. Available at: Abstracts_GCOS_Science_Conference_24March2016.pdf (accessed: $\overline{20}$ 06.2016).

5. Margaryan, V.G. (2017). The problems of change climate conditions for the period of over the last century over mountainous territory of Armenian Republic. Abstract book: Zaragoza 5th Open Science Meeting. Global challenges for our Common Future a Paleoscience Perspective, 9-13 May, Zaragoza, Spain, p. 310.

6. Ministry of Nature Protection of the Republic of Armenia (2015). Armenia's Third National Communication on Climate Change. Yerevan : Lusabats.

7. Margaryan, V.G., Guloyan, G.V. (2017). The vulnerability and risk assessment of agricultural crops in the conditions of expected climate change in the Republic of Armenia. Book of Abstracts: MACSUR Science Conference, 22-24 May, Berlin, p. 103.

8. Margaryan, V.G., Mkhitaryan, M.S. (2017). Assessment of viticulture and winemaking vulnerability in the expected conditions of climate change in Ararat valley and foothills. Book of Abstracts: MACSUR Science Conference, 22-24 May, Berlin, p. 102.

9. Margaryan, V.G., Mkhitaryan, M.S., Simonyan, L.M. (2017). Assessment and analysis of heat-providing vulnerability of main viticulture industrial region of Armenia in expected climate change. International conference landscape dimensions of sustainable development: science - planning governance. Book of Abstracts. ICLDS-2017, 4-6 October, Tbilisi, Georgia, pp. 69-70.

\title{
ОЦЕНКА И АНАЛИЗ УЯЗВИМОСТИ ТЕПЛООБЕСПЕЧЕНИЯ В ОСНОВНОМ ВИНОДЕЛЬЧЕСКОМ РАЙОНЕ АРМЕНИИ (АРАРАТСКАЯ ДОЛИНА И ПРЕДГОРНАЯ ЗОНА) В КОНТЕКСТЕ ОЖИДАЕМОГО ИЗМЕНЕНИЯ КЛИМАТА
}

\author{
В. Г. Маргарян ${ }^{1}$, канд. геогр. наук, М. С. Мхитарян ${ }^{2}$ \\ ${ }^{1}$ Ереванский государственный университет, \\ Республика Армения, г. Ереван, 0025, ул. Алека Манукяна, 1, vmargaryan@ysu.am \\ ${ }^{2}$ Министерство по чрезвычайным ситуачиям Республики Армения "Служба \\ по гидрометеорологии и активным воздействиям на атмосферные явления" \\ Республика Армения, Ереван 0054, Давиташен, 4-ьий квартал, ул. А. Микояна 109/8
}

В работе изучены и оценены условия теплообеспеченности основного района промышленного виноградарства Республики Армения (Араратская равнина и ее предгорная зона) в контексте изменения климата. В качестве исходново материала в работе использованы ежеедневные данные фактических наблюдений метеостанций на изучаемой территории гидрометслужбы МЧС Армении, а также агроклиматические справочники.

Теплообеспеченность сельскохозяйственных культур характеризуется суммой температур выше 5 и $10^{\circ} \mathrm{C}$. Суммой температур выше $10^{\circ} \mathrm{C}$ (активных температур) обусловлена продолжительность и теплообеспеченность вегетационного периода растений, что имеет определенное воздейстие на выбор сортов, накопление сахара в плодах и на специализацию. Согласно фактическим наблюдениям, годовая сумма температур выше $10^{\circ} \mathrm{C}$ в среднем составляет $3176-4220^{\circ} \mathrm{C}$.

В результате исследований выяснилось, что в основном районе промышленного виноградарства республики наблюдается рост теплообеспеченности. А продолжение роста при- 
ведет к изменению качества, формы, вкуса винограда, распространению болезней, расширению географии; под воздействием изменения климата до 2100 года ожидается смещение соответсвующей зоны для возделывания любой культуры, в том числе винограда, вверх от 100-200 до 400 м. На изучаемой территории в условиях ожидаемого роста температуры растет также и продолжительность вегетационного периода. То есть, в результате этого вегетация начинается раньше, что, с одной стороны, создаются благоприятные термические условия для возделывания винограда, а с другой стороны, увеличивается степень уязвимости винограда к неблагоприятным и опасным метеорологическим явлениям. Кроме того, комбинирование роста температуры и испарения и уменьшение осадков приведет к сокращению продуктивности винограда, к дополнительной потребности в оросительной воде, вторичному засолению почв, и, как следствие, к росту расходов. Таким образом, необходимо провести серьезные научные исследования, разработать новую стратегию, найти новые зоны виноградников и культивировать наиболее продуктивные новые сорта для указанных условий.

Ключевые слова: виноград, теплообеспечение, уязвимость, изменение климата, главный винодельческий район, Араратская долина и предгорная зона.

\title{
ОЦІНКА І АНАЛІЗ ВРАЗЛИВОСТІ ТЕПЛОЗАБЕЗПЕЧЕННЯ В ОСНОВНОМУ ВИНОРОБНОМУ РАЙОНІ ВІРМЕНІЇ (АРАРАТСЬКА ДОЛИНА І ПЕРЕДГІРНА ЗОНА) В КОНТЕКСТІ ОЧІКУВАНОЇ ЗМІНИ КЛІМАТУ
}

\author{
В. Г. Маргарян ${ }^{1}$, канд. геогр. наук, М. С. Мхітарян ${ }^{2}$ \\ ${ }^{1}$ Среванскій державний університет, vmargaryan@ysu.am \\ Республіка Вірменія, м. Среван, 0025, вул. А. Манукяна, 1, vmargaryan@ysu.am \\ ${ }^{2}$ Міністерство з надзвичайних ситуацій Республіки Вірменія "Служба \\ по гідрометеорології та активних дій на атмосферні явища" \\ Республіка Вірменія, Среван 0054, Давітамен, 4-ий квартал, вул. А. Мікояна 109/8
}

У роботі вивчені і оцінені умови теплозабезпечення основного району промислового виноградарства Республіки Вірменія (Араратська рівнина і їі передгірна зона) в контексті зміни клімату. В якості вихідного матеріалу в роботі використані щоденні дані фактичних спостережень метеостанцій на території, що вивчається, гідрометслужби МНС Вірменії, а також агрокліматичні довідники.

Теплозабезпечення сільськогосподарських культур характеризується сумою температур вище 5 i $10{ }^{\circ} \mathrm{C}$. Сумою температур вище $10^{\circ} \mathrm{C}$ (активних температур) обумовлена тривалість і теплозабезпечення вегетаційного періоду рослин, що має певний вплив на вибір сортів, накопичення цукру в плодах і на спеціалізацію. Згідно з фактичними спостереженнями, річна сума температур вище $10^{\circ} \mathrm{C}$ в середньому становить $3176-4220{ }^{\circ} \mathrm{C}$.

В результаті досліджень з'ясувалося, що в основному районі промислового виноградарства республіки спостерігається зростання теплозабезпечення. А продовження зростання призведе до зміни якості, форми, смаку винограду, поширенню хвороб, розширенню географії, під впливом зміни клімату до 2100 року очікується зсув відповідної зони для обробітку будь-якої культури, в тому числі винограду, вгору від 100-200 до 400 м. На досліджуваній території в умовах очікуваного зростання температури зростає також і тривалість вегетаційного періоду. Тобто, в результаті цього вегетація починається раніше, що, з одного боку, створює сприятливі термічні умови для обробітку винограду, а з іншого боку, збільшує ступінь уразливості винограду до несприятливих і небезпечних метеорологічних явищ. Крім того, комбінування зростання температури і випаровування і зменшення опадів призведе до скорочення продуктивності винограду, до додаткової потреби в зрошувальній воді, вторинного засолення грунтів, i, як наслідок, до зростання витрат. Таким чином, необхідно провести серйозні наукові дослідження, розробити нову стратегію, знайти нові зони виноградників і культивувати найбільш продуктивні нові сорти для зазначених умов.

Ключові слова: виноград, теплозабезпечення, вразливість. зміна клімату, головний виноробний район, Араратська долина і передгірна зона. 